\title{
DAYA SAING BAWANG MERAH DI WILAYAH SENTRA PRODUKSI DI INDONESIA
}

\author{
Haris Fatori Aldila*), Anna Fariyanti**), dan Netti Tinaprilla**) \\ *) Program Pascasarjana Magister Sains Agribisnis, Institut Pertanian Bogor \\ Jl. Kamper, Wing 4 Level 3, Kampus IPB Dramaga, Bogor 16680 \\ ${ }^{* *)}$ Departemen Agribisnis, Fakultas Ekonomi dan Manajemen, Institut Pertanian Bogor \\ J1. Kamper Wing 2 Level 5, Kampus IPB Darmaga Bogor 16680
}

\begin{abstract}
The objectives of this study are to analyze (1) the profitability of shallot farming, (2) competitiveness of shallot farming through competitive and comparative advantages and (3) impact of government's policy on competitiveness of shallot farming in three production centers in Indonesia (Cirebon, Brebes, and Tegal). Data analysis method used Policy Analysis Matrix (PAM). The results show that shallot farming in Cirebon, Brebes and Tegal is financially profitable but economically unprofitable. The analysis of the competitiveness of shallot farming in Cirebon, Brebes and Tegal shows that shallot farming has no comparative advantage but has competitive advantage. The impacts of government's policy on output show that the government has given protection on the price of shallot. Meanwhile, the government's policy on input is disincentive to farmers. Shallot farmers have to pay inputs more expensive than they should be; however, simultaneously, the government's policy on input and output support the shallot production in Cirebon, Brebes and Tegal.
\end{abstract}

Keywords: comparative advantage, competitive advantage, government's policy, policy analysis matrix, shallot

\begin{abstract}
ABSTRAK
Tujuan dari penelitian ini adalah menganalisis keuntungan usaha tani bawang merah, menganalisis daya saing bawang merah melalui keunggulan kometitif dan komparatif, serta menganalisis dampak kebijakan pemerintah pada usaha tani bawang merah di tiga sentra produksi di Indonesia (Cirebon, Brebes, Tegal). Metode analisis data menggunakan PAM (Policy Analysis Matrix). Hasil penelitian menunjukkan bahwa usaha tani bawang merah di Cirebon, Brebes dan Tegal menguntungkan secara finansial tetapi tidak menguntungkan secara ekonomi. Hasil analisis daya saing usaha tani bawang merah di Cirebon, Brebes dan Tegal menunjukkan usaha tani bawang merah tidak memiliki keunggulan komparatif tetapi masih memiliki keunggulan kompetitif. Dampak kebijakan pemerintah terhadap output menunjukkan adanya proteksi pemerintah terhadap harga bawang merah. Sementara itu, kebijakan pemerintah terkait input masih bersifat disinsentifkepada petani. Petani harus membayar input lebih mahal dari seharusnya. Secara simultan, kebijakan pemerintah terhadap input dan output mendukung terhadap produksi bawang merah di Cirebon, Brebes dan Tegal.
\end{abstract}

Kata kunci: bawang merah, kebijakan pemerintah, keunggulan komparatif, keunggulan kompetitif, policy analysis matrix

\footnotetext{
${ }^{1}$ Alamat Korespondensi:

Email: harisfatori@gmail.com
} 


\section{PENDAHULUAN}

Peningkatan daya saing produk pertanian telah menjadi perhatian utama pemerintah karena Indonesia dihadapkan pada pasar yang semakin liberal. Salah satu bentuk liberalisasi perdagangan tersebut adalah kesepakatan kerja sama Masyarakat Ekonomi ASEAN (MEA). Liberalisasi perdagangan dapat memberikan peluang terhadap pengembangan produk pertanian karena pasar komoditas pertanian akan semakin luas sejalan dengan dihapuskannya berbagai hambatan perdagangan antar negara (Irawan, 2003). Dengan dihapuskannya hambatan perdagangan akan mendorong persaingan yang semakin kompetitif dan semakin terintegrasinya pasar komoditas antar negara (Lakra et al. 2014; Saptana et al. 2006). Namun, liberalisasi perdagangan juga dapat menjadi ancaman apabila komoditas pertanian yang dihasilkan petani di dalam negeri tidak mampu bersaing dengan komoditas pertanian dari negara lain (Supriyati dan Rachman, 2003). Salah satu komoditas pertanian yang mendapat perhatian khusus dari pemerintah dalam rangka peningkatan produksi dan daya saing dalam negeri adalah bawang merah.

Bawang merah merupakan salah satu komoditas hortikultura bernilai tinggi (high value comodity) sehingga banyak petani yang mengusahakannya. Menurut Dinas Pertanian Kabupaten Bandung (2006) yang dikutip dalam Natawidjaja (2007) menyebutkan bahwa keuntungan mengusahakan bawang merah dapat mencapai Rp40.042.000/ha/musim, jauh lebih besarjika dibandingkan dengan keuntungan dari budi daya padi (Rp6.599.500/ha/musim) atau jagung (Rp4.550.000/ ha/musim). Total jumlah produksi bawang merah di Indonesia pada tahun 2014 mencapai 1,23 juta ton, meningkat 21,48\% dibandingkan dengan tahun 2013 yang hanya mencapai 1,01 juta ton.

Meskipun Indonesia mampu memproduksi bawang merah sendiri, sampai saat ini Indonesia masih menjadi net importer bawang merah. Pada tahun 2014, volume impor bawang merah mencapai 74.903 ton, sedangkan volume ekspornya hanya 4.439 ton (Pusdatin, 2015). Masih tingginya volume impor bawang merah ini disebabkan oleh rendahnya produktivitas, produksi musiman dan tingginya biaya produksi. Rata-rata produktivitas bawang merah di Indonesia pada tahun 2014 hanya mencapai 10,23 ton/ha (BPS, 2015), sedangkan produktivitas potensialnya bisa mencapai 20 ton/ha. Rendahnya produktivitas bawang merah terkait dengan rendahnya kualitas input yang digunakan terutama benih. Petani bawang merah menggunakan benih dari penanaman sebelumnya secara berulangulang sehingga produktivitasnya semakin menurun (Darwis et al. 2004). Selain kualitas input rendah, serangan hama pada bawang merah semakin sulit untuk ditangani karena hama terutama ulat semakin resisten terhadap obat-obatan akibat dari penyemprotan yang berlebihan (Moekasan dan Basuki, 2007). Selain produktivitasnya rendah, pasokan bawang merah juga tidak tersedia sepanjang waktu karena budi daya bawang merah dilakukan secara musiman, yaitu pada musim kemarau antara bulan April-September (on season). Hal tersebut menyebabkan akan terjadi kekurangan pasokan pada saat off season yang menyebabkan terjadi impor bawang merah yang tinggi. Petani bawang merah juga dihadapkan pada kendala tingginya biaya produksi. Usaha tani bawang merah membutuhkan biaya yang tinggi terutama untuk benih dan tenaga kerja (Nurasa dan Darwis, 2007; Asih, 2009; Mayrowani dan Darwis, 2010).

Menurut Kusuma dan Firdaus (2015) meskipun bawang merah merupakan sayuran unggulan Indonesia, bawang merah belum dapat bersaing di pasar dunia dengan kuat karena bawang merah tidak memiliki keunggulan komparatif. Bawang merah Indonesia belum dapat berdaya saing dengan baik jika dibandingkan dengan negara pesaingnya salah satunya Cina. Dalam rangka mendukung perkembangan produksi bawang merah dan peningkatkan daya saing bawang merah dalam negeri, pemerintah telah mengeluarkan kebijakan harga referensi impor. Pada tahun 2013, pemerintah melalui Kementerian Perdagangan telah mengeluarkan kebijakan ketentuan impor produk hortikultura melalui Peraturan Menteri Perdagangan Nomor 47/MDAG/ PER/8/2013. Kebijakan tersebut mengatur kegiatan impor lebih ketat pada produk hortikultura terutama cabai dan bawang merah. Berdasarkan kebijakan tersebut, pemerintah telah menetapkan harga referensi impor untuk cabai dan bawang merah melalui Keputusan Direktur Jenderal Perdagangan Dalam Negeri No. 118/ $\mathrm{PDN} / \mathrm{KEP} / 10 / 2013$. Harga referensi impor bawang merah ditetapkan sebesar Rp25.700/kg.

Terkait dengan pembatasan impor bawang merah, pemerintah sebelumnya juga telah mentapkan tarif impor yang relatif tinggi pada bawang merah yaitu sebesar 20\% melalui Peraturan Menteri Keuangan No. 213/PMK.011/2011. Pembatasan impor bawang merah diharapkan mampu menekan terjadinya penurunan 
harga yang tinggi pada saat bawang merah impor masuk ke Indonesia. Upaya pemerintah untuk mengatur impor bawang merah merupakan salah satu langkah untuk melindungi petani bawang merah dan mendorong peningkatan produksi bawang merah di dalam negeri. Bentuk kebijakan pemerintah lainnya yang mendukung perkembangan produksi bawang merah di dalam negeri yaitu adanya kebijakan subsidi pupuk, subsidi bunga kredit dan subsidi bahan bakar minyak. Kebijakankebijakan yang sudah dikeluarkan oleh pemerintah tersebut diduga mampu memberikan insentif positif bagi petani sehingga dapat meningkatkan keuntungan usaha tani bawang merah dan dapat meningkatkan daya saing bawang merah di Indonesia.

Tujuan dari penelitian ini, yaitu menganalisis tingkat profitabilitas finansial dan ekonomi usaha tani bawang merah di wilayah sentra produksi di Indonesia; menganalisis daya saing bawang merah di wilayah sentra produksi di Indonesia; dan menganalisis dampak kebijakan pemerintah terhadap daya saing bawang merah di wilayah sentra produksi di Indonesia.

\section{METODE PENELITIAN}

Penelitian dilaksanakan di tiga kabupaten sentra produksi yang terletak di Provinsi Jawa Tengah dan Jawa Barat. Pemilihan lokasi dilakukan secara purposive. Sentra produksi bawang merah di Jawa Tengah yang dipilih adalah Kabupaten Brebes dan Kabupaten Tegal, sedangkan untuk Jawa Barat adalah Kabupaten Cirebon. Penelitian ini dilaksanakan pada bulan November 2014 sampai bulan Agustus 2015.

Data yang digunakan dalam penelitian ini merupakan data sekunderyang diperoleh dari data penelitian tematik bawang merah Pusat Kajian Hortikultura Tropika (PKHT) IPB tahun 2014. Jumlah data responden yang digunakan dalam penelitian ini sebanyak 40 petani bawang merah di masing-masing kabupaten sehingga total responden sebanyak 120 petani bawang merah. Data pendukung lainnya juga dikumpulkan untuk menunjang penelitian ini yang diperoleh dari instansiinstansi terkait dan literatur-literatur yang relevan dengan topik penelitian yang berasal dari buku, jurnal, dan internet.

Analisis daya saing dan dampak kebijakan pemerintah pada usaha tani bawang merah menggunakan metode Policy Analysis Matrix (PAM). Adapun tahapan dalam analisis dengan metode PAM adalah menentuan komponen input dan output usaha tani bawang merah, memisahkan komponen biaya menjadi biaya tradable (asing) dan non tradable (domestik), menentukan harga bayangan, dan menganalisis indikator matrik kebijakan dalam PAM. Secara lengkap tabulasi matrik analisis kebijakan (PAM) dapat dilihat pada Tabel 1.

\section{HASIL}

\section{Keuntungan Finansial dan Ekonomi Usaha Tani Bawang Merah}

Indikator keuntungan finansial usaha tani bawang merah dapat dilihat dari nilai keuntungan privatnya. Keuntungan privat usaha tani bawang merah mengukur tingkat keuntungan berdasarkan harga input dan output aktual. Secara umum keuntungan privat usaha tani bawang merah di Kabupaten Cirebon relatif lebih tinggi dibandingkan dengan keuntungan privat di Kabupaten Brebes dan Kabupaten Tegal (Tabel 2). Tingginya keuntungan di Kabupaten Cirebon dipengaruhi oleh tingginya produktivitas bawang merah yang dihasilkan petani sehingga penerimaan yang diterima petani juga besar. Produktivitas bawang merah antar musim di Kabupaten Cirebon berkisar antara 11,3-14,1 ton/ ha, sedangkan di Kabupaten Brebes dan Tegal secara berturut-turut berkisar antara 8,2-9,1 ton/ha dan 8,79,8 ton/ha. Besarnya keuntungan privat yang diperoleh petani bervariasi antar musim. Usaha tani bawang merah di Kabupaten Cirebon mampu menghasilkan keuntungan tertinggi pada musim kemarau II. Sementara itu, usaha tani bawang merah di Kabupaten Brebes dan Tegal mencapai keuntungan tertinggi pada saat musim hujan.

Indikator keuntungan ekonomi dapat dilihat dari nilai keuntungan sosial usaha tani bawang merah. Keuntungan sosial adalah keuntungan yang dihitung berdasarkan harga sosial atau harga bayangan. Berdasarkan perhitungan keuntungan sosial, usaha tani bawang merah di Kabupaten Cirebon, Brebes, dan Tegal mengalami kerugian (Tabel 2). Rata-rata kerugian yang diterima oleh petani di Kabupaten Cirebon, Brebes dan Tegal secara berturut-turut sebesar Rp36.622.281/ ha, Rp45.514.510/ha dan Rp45.424.099/ha. Besarnya nilai kerugian yang diterima petani tersebut disebabkan oleh rendahnya penerimaan sosial usaha tani bawang merah karena harga bayangan bawang merah jauh lebih rendah daripada harga aktualnya. Harga bayangan 
bawang merah diperoleh dari harga FOB (free on board) bawang merah impor. Hasil perhitungan menunjukkan harga bayangan bawang merah di Kabupaten Cirebon sebesar Rp4.154/kg, di Kabupaten Brebes Rp4.161/ $\mathrm{kg}$, dan di Kabupaten Tegal Rp4.162/kg. Sebagai pembanding, rata-rata harga aktual bawang merah di Kabupaten Cirebon Rp12.873/kg, di Kabupaten Brebes Rp8.638/kg dan di Kabupaten Tegal Rp9.323/kg.

\section{Daya saing Usaha Tani Bawang Merah}

Indikator yang digunakan dalam menentukan daya saing usaha tani bawang merah dalam penelitian ini menggunakan pendekatan keunggulan kompetitif dan komparatif. Keunggulan kompetitif menunjukkan sejauhmana usaha tani bawang merah tersebut mampu membiayai faktor domestiknya pada harga privat atau aktual dengan menggunakan indikator nilai Private Cost Ratio (PCR). Nilai PCR kurang dari satu menunjukkan komoditas tersebut memiliki keunggulan kompetitif. Hasil analisis pada Tabel 2 menunjukkan bahwa usaha tani bawang merah di Kabupaten Cirebon, Brebes, dan Tegal memiliki keunggulan kompetitif pada musimmusim tertentu. Nilai PCR yang diterima petani bawang merah di Kabupaten Cirebon berkisar antara 0,80-1,14, di Brebes 0,96-1,03 dan di Tegal 0,79-1,22. Petani bawang merah di Kabupaten Cirebon memiliki keunggulan kompetitif pada musim kemarau I dan kemarau II, petani di Kabupaten Brebes pada musim hujan dan petani di Kabupaten Tegal pada musim hujan dan musim kemarau II. Indikator daya saing usaha tani bawang merah di Cirebon, Brebes dan Tegal secara lebih jelas dapat dilihat pada Tabel 3 .

Tabel 1. Tabulasi matrix analisis kebijakan

\begin{tabular}{|c|c|c|c|c|}
\hline \multirow{2}{*}{ Uraian } & \multirow{2}{*}{ Pendapatan } & \multicolumn{2}{|c|}{ Biaya } & \multirow{2}{*}{ Keuntungan } \\
\hline & & Input tradable & Input non tradable & \\
\hline Harga privat & $\mathrm{A}$ & $\mathrm{B}$ & $\mathrm{C}$ & $\mathrm{D}$ \\
\hline Harga sosial & $\mathrm{E}$ & $\mathrm{F}$ & G & $\mathrm{H}$ \\
\hline Efek divergensi & I & $\mathrm{J}$ & $\mathrm{K}$ & $\mathrm{L}$ \\
\hline
\end{tabular}

Sumber: Monke and Pearson, 1989

Keterangan:

Keuntungan privat $(\mathrm{D})=\mathrm{A}-(\mathrm{B}+\mathrm{C})$

Keuntungan sosial $(\mathrm{H})=\mathrm{E}-(\mathrm{F}+\mathrm{G})$

Rasio biaya privat $(\mathrm{PCR})=\mathrm{C} /(\mathrm{A}-\mathrm{B})$

Rasio biaya sumber daya domestik $(\mathrm{DRCR})=\mathrm{G} /(\mathrm{E}-\mathrm{F})$

Transfer output (I) = A - E

Koefisien proteksi output nominal $(\mathrm{NPCO})=\mathrm{A} / \mathrm{E}$
Transfer input tradable $(\mathrm{J})=\mathrm{B}-\mathrm{F}$

Transfer input non tradable $(\mathrm{K})=\mathrm{C}-\mathrm{G}$

Koefisien proteksi input nominal (NPCI) $=\mathrm{B} / \mathrm{F}$

Transfer bersih $(\mathrm{L})=\mathrm{D}-\mathrm{H}$

Koefisien proteksi efektif $(\mathrm{EPC})=(\mathrm{A}-\mathrm{B}) /(\mathrm{E}-\mathrm{F})$

Rasio subsidi bagi produsen $(\mathrm{SRP})=\mathrm{L} / \mathrm{E}$

Tabel 2. Keuntungan privat dan sosial usaha tani bawang merah di Cirebon, Brebes dan Tegal per hektar per musim tanam (dalam juta rupiah) tahun 2013-2014

\begin{tabular}{lcccccc}
\hline \multirow{2}{*}{ Lokasi } & \multicolumn{3}{c}{ Privat (Finansial) } & \multicolumn{3}{c}{ Sosial (Ekonomi) } \\
\cline { 2 - 7 } Cirebon & Penerimaan & Biaya & Keuntungan & Penerimaan & Biaya & Keuntungan \\
MH & & & & & & \\
MK I & 87.982 & 99.146 & -11.164 & 46.888 & 78.168 & -31.280 \\
MK II & 123.814 & 103.432 & 20.382 & 54.971 & 80.348 & -25.377 \\
Brebes & 133.118 & 108.497 & 24.621 & 58.585 & 90.679 & -32.094 \\
MH & & & & & & \\
MK I & 97.217 & 93.511 & 3.706 & 34.065 & 75.121 & -41.056 \\
MK II & 93.453 & 93.238 & 214 & 38.041 & 83.989 & -45.947 \\
Tegal & 91.089 & 93.865 & -2.777 & 35.725 & 80.555 & -44.831 \\
MH & & & & & & \\
MK I & 114.229 & 92.449 & 21.780 & 36.375 & 74.024 & -37.650 \\
MK II & 79.994 & 95.600 & -15.606 & 39.172 & 88.032 & -48.859 \\
\hline
\end{tabular}


Tabel 3. Indikator daya saing usaha tani bawang merah di Cirebon, Brebes dan Tegal per hektar per musim tanam tahun 2013-2014

\begin{tabular}{cccccccccc}
\hline Indikator & \multicolumn{3}{c}{ Cirebon } & \multicolumn{3}{c}{ Brebes } & \multicolumn{3}{c}{ Tegal } \\
\cline { 2 - 10 } & MH & MK I & MK II & MH & MK I & MK II & MH & MK I & MK II \\
\hline PCR & 1,14 & 0,82 & 0,80 & 0,96 & 1,00 & 1,03 & 0,79 & 1,22 & 0,99 \\
DRCR & 1,79 & 1,53 & 1,66 & 2,50 & 2,51 & 2,60 & 2,32 & 2,59 & 2,16 \\
\hline
\end{tabular}

Dari hasil Tabel 3 dapat dilihat bahwa usaha tani bawang merah di Kabupaten Cirebon relatif lebih memiliki keunggulan kompetitif daripada usaha tani bawang merah di Kabupaten Brebes dan Tegal. Hal ini dikarenakan masih tingginya produktivitas bawang merah yang mampu dicapai oleh petani di Kabupaten Cirebon dibandingkan dengan kabupaten lainnya. Apabila dilihat berdasarkan musim, Kabupaten Cirebon memiliki keunggulan kompetitif dalam melakukan usaha tani bawang merah pada musim kemarau I dan kemarau II, sedangkan Kabupaten Brebes dan Tegal memiliki keunggulan kompetitif pada musim hujan. Pada musim hujan, harga bawang merah di Brebes dan Tegal lebih tinggi dibandingkan Cirebon yaitu masingmasing Rp11.875/kg dan Rp13.071/kg. Sementara itu di Cirebon hanya sebesar Rp7.795/kg.

Indikator lainnya dalam menentukan daya saing adalah keunggulan komparatif. Keunggulan komparatif mencerminkan efisiensi dalam penggunaan sumber daya domestik, dengan kata lain, sejauhmana sumber daya domestik dapat dihemat untuk menghasilkan satu satuan devisa. Indikator keunggulan komparatif menggunakan nilai Domestic Resource Cost Ratio (DRCR). Nilai DRCR kurang dari satu menunjukkan komoditas tersebut memiliki keunggulan komparatif. Usaha tani bawang merah di Kabupaten Cirebon, Brebes, dan Tegal tidak memiliki keunggulan komparatif baik pada musim hujan, kemarau I, maupun kemarau II. Tabel 2 menunjukkan nilai DRCR di setiap kabupaten dan musim seluruhnya bernilai lebih dari satu, artinya usaha tani bawang merah tersebut tidak efisien dalam penggunaan sumber daya domestik. Dengan kata lain, memproduksi bawang merah dalam negeri jauh lebih mahal daripada mengimpor bawang merah dari luar negeri. Hasil penelitian ini berbeda dengan hasil penelitian sebelumnya yang menunjukkan bahwa usaha tani bawang merah di Indonesia masih memiliki keunggulan komparatif dan kompetitif karena nilai PCR dan DRCR kurang dari satu (Purmiyati, 2002; Rachman et al. 2004).

Beberapa penelitian sebelumnya menunjukkan bahwa rendahnya produktivitas suatu komoditas pertanian menyebabkan keunggulan komparatifnya lemah (Mohanty et al. 2003; Amirteimoori dan Chizari, 2008; Kapaj et al. 2010). Hal yang sama juga terjadi pada usaha tani bawang merah di Indonesia. Produktivitas aktual bawang merah di lokasi penelitian berkisar antara $8,2-14,1$ ton/ha. Nilai ini masih jauh dari produktivitas potensial yang seharusnya dapat dicapai, yaitu 20 ton/ha. Penyebab rendahnya produktivitas ini adalah rendahnya kualitas benih yang digunakan petani karena petani tidak menggunakan benih bersertifikat. Petani di ketiga lokasi penelitian lebih banyak menggunakan benih yang berasal dari hasil panen sebelumnya dan dilakukan secara berulangulang. Selain dari benih sendiri, petani juga membeli benih dari petani lain. Penggunaan benih yang tidak bersertifikat dikhawatirkan membawa virus atau penyakit yang dapat menyebabkan produksi bawang merah menurun. Gunaeni et al. (2011) dan Kurniawan dan Suastika (2013) menemukan bahwa benih bawang merah varietas lokal asal Jawa Barat dan Jawa Tengah mengandung virus shallot yellow stripe virus dan onion yellow draft virus.

Rendahnya produktivitas juga disebabkan oleh menurunya kesuburan lahan karena lahan sudah jenuh dengan bahan kimia baik dari pupuk maupun obatobatan. Di ketiga lokasi penelitian, penggunaan pupuk kimia dan obat-obatan pada bawang merah sangat intensif sementara penggunaan pupuk organik masih rendah. Tingginya serangan hama dan penyakit juga menjadi penyebab rendahnya produktivitas bawang merah di ketiga lokasi penelitian. Semakin tingginya serangan hama dan penyakit ini dipengaruhi oleh perubahan iklim (Rosenzweig et al. 2001; Garrett et al. 2006), resistensi hama terhadap obat-obatan (Moekasan dan Basuki, 2007) dan aplikasi obat-obatan yang kurang tepat (Basuki, 2009). Petani bawang merah melakukan penyemprotan pestisida tiga hari sekali, bahkan apabila tingkat serangan hama tinggi bisa dua hari sekali. Penyemprotan mulai dilakukan pada saat tanaman berumur 10 hari hingga tanaman siap akan dipanen. Jenis obat-obatan yang digunakan untuk penyemprotan juga lebih dari satu jenis yang dicampur menjadi satu dalam tangki semprot. Intensitas penyemprotan yang 
tinggi dan penggunaan berbagai jenis obat-obatan yang dicampur menjadi satu menyebabkan hama semakin resisten terhadap pemberian obat-obatan. Kasimin (2013) juga menunjukkan hal yang serupa yaitu pemakaian pupuk dan pestisida yang tidak tepat dosis, tidak tepat jenis, dan tidak tepat waktu akan menurunkan produktivitas tanaman hortikultura unggulan di Provinsi Aceh. Semakin banyak jumlah pupuk dan pestisida yang digunakan petani maka semakin rendah tingkat produksi yang akan diperoleh, dan begitu juga sebaliknya.

Tingginya biaya produksi bawang merah juga berkontribusi terhadap lemahnya daya saing bawang merah di ketiga lokasi penelitian. Tingginya harga benih bawang merah menjadi salah satu penyebab tingginya biaya produksi. Rata-rata harga benih di Kabupaten Cirebon, Brebes dan Tegal secara berturut-turut sebesar Rp18.750/kg, Rp16.020/kg dan Rp17.019/kg. Ratarata persentase pengeluaran untuk benih bawang merah terhadap total biaya di Kabupaten Cirebon, Brebes dan Tegal masing-masing sebesar 30,33\%, 27,75\%, dan 30,04\%. Selain benih, pengeluaran untuk tenaga kerja juga besar. Rata-rata persentase pengeluaran untuk tenaga kerja di Kabupaten Cirebon, Brebes dan Tegal secara berturut-turut sebesar 41,43\%, 46,28\% dan $36,70 \%$. Penggunaan tenaga kerja tertinggi untuk pengolahan lahan (31\%), penyiraman $(21 \%)$ dan pengendalian hama (12\%). Risiko pada usaha tani bawang merah juga tinggi terutama pada risiko produksi. Menurut Lawalata (2013), risiko produksi bawang merah mencapai $85,15 \%$. Hal tersebut menyebabkan pengeluaran petani untuk pestisida juga tinggi mencapai Rp5.189.529-7.570.764/ha/musim. Secara umum, komponen pengeluaran terbesar dalam usaha tani bawang merah di ketiga lokasi penelitian adalah untuk benih dan tenaga kerja. Dari kajian yang sama, Nurasa dan Darwis (2007), Asih (2009), Mayrowani dan Darwis (2010) dan Rosyadi dan Purnomo (2014) juga menunjukkan bahwa biaya terbesar dalam usaha tani bawang merah untuk benih dan tenaga kerja.

\section{Dampak Kebijakan Pemerintah terhadap Daya Saing Bawang Merah}

Dampak kebijakan pemerintah pada usaha tani bawang merah dibedakan menjadi tiga yaitu dampak kebijakan output, dampak kebijakan input dan dampak kebijakan input-output. Dampak kebijakan pemerintah terkait output dapat dilihat dengan indikator nilai transfer output dan Nominal Protection Coeficient Output
(NPCO). Dampak kebijakan pemerintah terhadap input pada usaha tani bawang merah dapat dilihat melalui tiga indikator, yaitu transfer input, transfer faktor dan Nominal Protection Coeficient Input (NPCI). Kebijakan pemerintah terhadap output maupun input dapat dilihat dampaknya secara bersama-sama melalui tiga indikator, yaitu nilai transfer bersih, Efective Protection Coeficient (EPC) dan Subsidi Ratio for Producen (SRP).

Kebijakan pemerintah terkait dengan output bawang merah memberikan dampak positif terhadap petani bawang merah di ketiga lokasi penelitian. Kebijakan pemerintah menetapkan harga referensi impor dan tarif impor bawang merah menyebabkan nilai transfer output bernilai positif seperti yang terlihat pada Tabel 4 . Hal ini berarti harga bawang merah yang diterima petani lebih tinggi daripada harga sosialnya sehingga petani memperoleh penerimaan lebih tinggi dari seharusnya. Kebijakan pemerintah terkait dengan penetapan harga referensi impor dan tarif impor bawang merah mampu mengendalikan aliran masuk bawang merah impor sehingga harga bawang merah di dalam negeri juga dapat dikendalikan. Adanya perbedaan nilai transfer output di ketiga kabupaten pada tiga musim tanam tersebut disebabkan oleh adanya perbedaan produktivitas dan harga aktual bawang merah.

Mekanisme impor bawang merah yang sudah diatur dengan ketat melalui kebijakan harga referensi impor dan tarif impor menghasilkan nilai NPCO di ketiga lokasi penelitian yang lebih dari satu (Tabel 4). Nilai NPCO lebih dari satu menunjukkan proteksi pemerintah terhadap output bawang merah masih tinggi sehingga menyebabkan harga yang diterima petani lebih tinggi daripada harga sebenarnya. Dampak dari kebijakan pembatasan impor tersebut yaitu petani bawang merah di Kabupaten Cirebon menerima harga bawang merah $88-127 \%$ lebih tinggi dari harga di pasar internasional. Sementara itu, di Kabupaten Brebes dan Tegal petani memperoleh harga bawang merah secara berturut-turut berkisar antara $146-185 \%$ dan 104-214\% lebih tinggi daripada harga di pasar internasional. Kariyasa (2003) juga mengungkapkan hasil temuan yang sama terkait dengan dampak kebijakan pemerintah pada tarif impor dan harga dasar terhadap penerimaan produsen beras. Menurut Kariyasa (2003), penetapan tarif impor dan harga dasar oleh pemerintah pada beras menyebabkan penerimaan produsen beras 23,91\% lebih tinggi dari seharusnya diterima ( $\mathrm{NPCO}=1,2391 \%)$. 
Pemerintah telah mengeluarkan beberapa kebijakan terkait dengan input usaha tani seperti kebijakan subsidi pupuk, subsidi bahan bakar minyak, dan juga subsidi kredit. Kebijakan pemerintah terkait input tersebut ternyata belum sepenuhnya dapat memberikan insentif positif terhadap petani. Petani bawang merah harus membayar input lebih mahal dari seharusnya karena tingkat proteksi pemerintah terhadap input usaha tani bawang merah lemah. Secara lebih jelas dampak kebijakan pemerintah terhadap input usaha tani bawang merah di Kabupaten Cirebon, Brebes dan Tegal dapat dilihat pada Tabel 5 .
Hasil pada Tabel 5 menunjukkan nilai transfer input dan transfer faktor di ketiga lokasi penelitian menunjukkan hasil yang positif. Nilai transfer input positif menunjukkan harga sosial input tradable lebih rendah daripada harga privatnya. Nilai transfer faktor positif menunjukkan harga sosial input non tradable lebih rendah daripada harga privatnya. Dengan kata lain, petani bawang merah membayar input tradable maupun non tradable lebih mahal dari yang seharusnya. Tingkat proteksi pemerintah terhadap input tradable di ketiga lokasi penelitian masih rendah. Nilai NPCI yang diperoleh di ketiga lokasi penelitian seluruhnya lebih besar dari satu.

Tabel 4. Indikator dampak kebijakan pemerintah terhadap output usaha tani bawang merah di Kabupaten Cirebon, Brebes, dan Tegal pada musim tanam tahun 2013-2014

\begin{tabular}{lcc}
\hline & \multicolumn{2}{c}{ Lokasi } \\
\cline { 2 - 3 } & Transfer output $(\mathrm{Rp} / \mathrm{Ha})$ & $\mathrm{NPCO}$ \\
\hline Kabupaten Cirebon & & 1,88 \\
Musim Hujan & $41.094 .184,19$ & 2,25 \\
Musim Kemarau I & $68.843 .236,18$ & 2,27 \\
Musim Kemarau II & $74.533 .023,34$ & \\
Kabupaten Brebes & & 2,85 \\
Musim Hujan & $63.151 .121,94$ & 2,46 \\
Musim Kemarau I & $55.411 .726,10$ & 2,55 \\
Musim Kemarau II & $55.363 .766,21$ & \\
Kabupaten Tegal & & 3,14 \\
Musim Hujan & $77.854 .824,08$ & 2,04 \\
Musim Kemarau I & $40.821 .341,40$ & 2,18 \\
Musim Kemarau II & $48.068 .549,40$ & \\
\hline
\end{tabular}

Tabel 5. Indikator dampak kebijakan pemerintah terhadap input usaha tani bawang merah di Kabupaten Cirebon, Brebes, dan Tegal pada musim tanam tahun 2013-2014

\begin{tabular}{lccc}
\hline \multirow{2}{*}{ Lokasi } & \multicolumn{3}{c}{ Indikator dampak kebijakan input } \\
\cline { 2 - 4 } Kabupaten Cirebon & Transfer input $(\mathrm{Rp} / \mathrm{Ha})$ & Transfer faktor (Rp/Ha) & NPCI \\
Musim Hujan & & & 1,31 \\
Musim Kemarau I & $2.232 .325,56$ & $18.782 .078,47$ & 1,35 \\
Musim Kemarau II & $2.370 .924,05$ & $20.749 .628,68$ & 1,06 \\
Kabupaten Brebes & $621.703,15$ & $17.240 .018,85$ & \\
Musim Hujan & & & 1,31 \\
Musim Kemarau I & $2.112 .371,28$ & $16.366 .387,39$ & 1,08 \\
Musim Kemarau II & $612.395,36$ & $8.741 .988,89$ & 1,15 \\
Kabupaten Tegal & $1.130 .591,63$ & $12.269 .025,08$ & 1,25 \\
Musim Hujan & & & 1,07 \\
Musim Kemarau I & $1.968 .070,05$ & $16.510 .789,17$ & 1,06 \\
Musim Kemarau II & $575.426,81$ & $7.004 .921,15$ & \\
\hline
\end{tabular}


Di Kabupaten Cirebon, petani harus membayar sekitar 6-35\% input tradable lebih mahal dari yang seharusnya dibayar. Sementara itu di Kabupaten Brebes dan Tegal petani harus membayar input tradable masing-masing sebesar $8-31 \%$ dan 6-25\% lebih mahal daripada seharusnya. Pemerintah menetapkan kebijakan pajak pada input tradable sehingga harga yang diterima lebih besar dari seharusnya. Adegbite et al. (2014) mengungkapkan hal yang sama bahwa adanya pajak pada input menyebabkan petani nanas di Nigeria harus membayar input lebih mahal dari yang seharusnya.

Kebijakan pemerintah terhadap subsidi pupuk dan bahan bakar menunjukkan adanya dampak positif yaitu petani membayar harga pupuk urea, TSP, phonska, dan bahan bakar minyak lebih murah dari seharusnya. Harga pupuk urea, TSP, phonska, dan bahan bakar minyak masing-masing sebesar 39-48\%, 25-42\%, $50-58 \%$ dan 54\% lebih murah dari harga seharusnya. Namun, petani harus membayar harga lebih mahal dari seharusnya untuk pupuk $\mathrm{KCl}$, pupuk $\mathrm{ZA}$ dan benih masing-masing sebesar $15-79 \%,-47 \%$, dan 128-224\%. Sementara itu untuk input lainnya seperti pupuk NPK mutiara, pupuk kamas, obat-obatan dan alat pertanian, petani membayar sesuai dengan harga seharusnya. Senada dengan hasil tersebut, Rachman et al. (2004) juga menunjukkan bahwa petani bawang merah di Indramayu dan Majalengka membayar harga pupuk $7-87 \%$ lebih mahal dari harga sebenarnya.

Secara parsial, kebijakan pemerintah terkait output mampu memberikan insentif positif terhadap petani. Sementara itu, kebijakan pemerintah terkait input masih bersifat disinsentif terhadap petani. Namun, secara bersama-sama, kebijakan input dan output usaha tani bawang merah yang berlaku di Indonesia masih mendukung terhadap produksi bawang merah dalam negeri seperti yang terlihat pada indikator nilai transfer bersih, EPC dan SRP pada Tabel 6.

Kebijakan pemerintah terhadap input dan output secara simultan dapat memberikan insentif bagi petani di ketiga lokasi penelitian yang tercermin dari nilai transfer bersih yang positif. Hal tersebut menunjukkan adanya tambahan surplus produsen yang disebabkan oleh kebijakan pemerintah pada input dan output. Tingkat proteksi pemerintah terhadap produksi bawang merah di ketiga lokasi penelitian juga tinggi yang tercermin pada nilai EPC lebih besar dari satu. Kebijakan pemerintah pada input dan output memberikan dukungan dalam pengembangan komoditas bawang merah dalam negeri dan mampu memberikan insentif bagi petani.

Nilai SRP yang diperoleh di semua lokasi penelitian menunjukkan angka positif. Nilai SRP lebih besar dari satu menunjukkan petani mengeluarkan biaya produksi yang lebih kecil dari biaya imbangan untuk berproduksi. Kebijakan pemerintah dapat menurunkan biaya produksi sebesar 43-163\%. Artinya, terjadi transfer dari pemerintah atau konsumen kepada petani sehingga petani menikmati tambahan keuntungan sebesar nilai SRP. Transfer bersih timbul sebagian besar akibat proteksi harga bawang merah di dalam negeri karena kebijakan pembatasan impor hortikultura, kebijakan harga referensi dan penetapan tarif impor bawang merah.

Tabel 6. Indikator dampak kebijakan pemerintah terhadap input dan output usaha tani bawang merah di Kabupaten Cirebon, Brebes, dan Tegal pada musim tanam tahun 2013-2014

\begin{tabular}{lccc}
\hline \multirow{2}{*}{ Lokasi } & \multicolumn{3}{c}{ Indikator dampak kebijakan input-output } \\
\cline { 2 - 4 } & Transfer bersih $(\mathrm{Rp} / \mathrm{Ha})$ & EPC & SRP \\
\hline Kabupaten Cirebon & & 1,98 & 0,43 \\
Musim Hujan & $20.079 .780,17$ & 2,38 & 0,83 \\
Musim Kemarau I & $45.722 .683,44$ & 2,53 & 0,97 \\
Musim Kemarau II & $56.671 .301,34$ & & \\
Kabupaten Brebes & & 3,23 & 1,31 \\
Musim Hujan & $44.672 .363,27$ & 2,80 & 1,21 \\
Musim Kemarau I & $46.057 .341,84$ & 2,93 & 1,17 \\
Musim Kemarau II & $41.964 .149,50$ & & \\
Kabupaten Tegal & & 3,66 & 1,63 \\
Musim Hujan & $59.375 .964,87$ & 2,31 & 0,85 \\
Musim Kemarau I & $33.200 .993,45$ & 2,46 & 0,93 \\
Musim Kemarau II & $38.144 .257,17$ & & \\
\hline
\end{tabular}




\section{Implikasi Manajerial}

Hasil penelitian dan simpulan yang diperoleh maka dapat dirumuskan terkait implikasi kebijakan, yaitu sebagai berikut upaya untuk peningkatan daya saing bawang merah dapat dilakukan dengan meningkatkan produktivitas bawang merah. Peningkatan produktivitas bawang merah dapat dilakukan melalui penggunaan benih bermutu, penggunaan varietas bawang merah yang memiliki produktivitas tinggi, adaptif, dan tahan terhadap hama dan penyakit, dan perbaikan dalam teknik budi daya sesuai SOP.

Dalam rangka menurunkan biaya produksi bawang merah yang tinggi dapat dilakukan dengan menurunkan harga benih bawang merah, pengurangan penggunaan pestisida dengan pengendalian hama ramah lingkungan, dan peningkatan keterampilan tenaga kerja untuk meningkatkan efisiensi penggunaan tenaga kerja. Kebijakan pemerintah terkait output, yaitu kebijakan harga referensi impor harus tetap dipertahankan karena mampu mengendalikan jumlah impor bawang merah di dalam negeri. Akan tetapi, pemerintah perlu melakukan pemantauan terhadap penentuan harga referensi impor dengan memperhatikan perkembangan produktivitas bawang merah dan biaya produksi di tingkat petani karena apabila terjadi perubahan produktivitas, perubahan penggunaan input dan perubahan pada harga-harga input pertanian akan menyebabkan biaya produksi juga berubah.

Terkait dengan kebijakan input, pemerintah harus lebih fokus pada upaya menurunkan harga benih melalui pengembangan kawasan benih bawang merah untuk meningkatkan pasokan benih bawang merah bermutu dan subsidi usaha pembibitan bawang merah untuk meningkatkan minat petani penangkar benih dalam melakukan budi daya benih bawang merah.

\section{KESIMPULAN DAN SARAN}

\section{Kesimpulan}

Hasil penelitian menunjukkan bahwa usaha tani bawang merah di kabupaten Cirebon, Brebes dan Tegal menguntungkan secara finansial, tetapi tidak menguntungkan secara ekonomi. Usaha tani bawang merah di ketiga lokasi penelitian lebih menguntungkan pada saat terdapat kebijakan pemerintah daripada tanpa kebijakan pemerintah. Secara keseluruhan, usaha tani bawang merah di di Kabupaten Cirebon, Brebes dan Tegal tidak memiliki daya saing. Dilihat berdasarkan keunggulan komparatif dan kompetitifnya, bawang merah di ketiga daerah penelitian tersebut masih memiliki keunggulan kompetitif, tetapi tidak memiliki keunggulan komparatif. Kebijakan pemerintah terhadap output bawang merah memberikan insentif positif bagi petani, sedangkan kebijakan pemerintah terhadap input masih bersifat disinsentif terhadap petani. Namun, secara bersama-sama, kebijakan input dan output usaha tani bawang merah yang berlaku di Indonesia memberikan insentif positif sehingga masih mendukung terhadap produksi bawang merah dalam negeri.

\section{Saran}

Bagi pihak yang tertarik untuk melakukan penelitian selanjutnya diharapkan dapat melakukan kajian mengenai perkembangan usaha dan daya saing usaha perbenihan bawang merah di Indonesia. Penelitian ini dibutuhkan untuk menggambarkan sejauh mana usaha perbenihan bawang merah yang dilakukan oleh penangkar benih di Indonesia terkait dengan ketersediaan benih bawang merah berkualitas sebagai salah satu upaya untuk peningkatan daya saing bawang merah di Indonesia.

\section{DAFTAR PUSTAKA}

Adegbite O, Oni O, Adeoye I. 2014. Competitiveness of Pineapple production in Osun State, Nigeria. Journal of Economics and Sustainable Development 5(2): 205-214.

Amirteimoori S, Chizari AH. 2008. An investigation of comparative advantage of pistachio production and exports in Iran. Journal of Agricultural Science and Technology 10: 395-403.

Asih DN. 2009. Analisis karakteristik dan tingkat pendapatan usaha tani bawang merah di Sulawesi Tengah. Jurnal Agroland 16(1): 53-59.

Basuki RS. 2009. Pengetahuan petani dan keefektifan penggunaan insektisida oleh petani dalam pengendalian ulat Spodoptera exigua Hubn. pada tanaman bawang merah di Brebes dan Cirebon. Jurnal Hortikultura 19(4): 459-474.

[BPS] Badan Pusat Statistik. 2015. Statistik Indonesia 2015. Jakarta: Badan Pusat Statistik. 
Darwis V, Irawan B, Muslim C. 2004. Keragaan benih hortikultura di tingkat produsen dan konsumen (studi kasus: bawang merah, cabai merah, kubis, dan kentang). Socio-Economic of Agriculturre and Agribusiness 4(2): 1-18.

Garrett KA, Dendy SP, Frank EE, Rouse MN, Travers SE. 2006. Climate change effects on plant disease: genomes to ecosystems. Annual Review of Phytopathology 44: 489-509. DOI: 10.1146/ annurev.phyto.44.070505.143420.

Gunaeni N, Wulandari AW, Duriat AS, Muharam A. 2011. Insiden penyakit virus tular umbi pada tigabelas varietas bawang merah asal Jawa Barat dan Jawa Tengah. Jurnal Hortikultura 21(2): 164-172. https://doi.org/10.21082/jhort. v21n2.2011.p164-172.

Irawan B. 2003. Agribisnis hortikultura: peluang dan tantangan dalam era perdagangan bebas. SocioEconomic of Agriculturre and Agribusiness 3(2): 146-160.

Kapaj AM, Kapaj I, Halbrendt CC, Totojani O. 2010. Assessing the comparative advantage of Albanian olive oil production. International Food and Agribusiness Management Review 13(1): 15-25.

Kariyasa K. 2003. Dampak tarif impor dan kinerja kebijakan harga dasar serta implikasinya terhadap daya saing beras di Indonesia di pasar dunia. Analisis Kebijakan Pertanian 1(4): 315-330.

Kasimin S. 2013. Keterkaitan produk dan pelaku dalam pengembangan agribisnis hortikultura unggulan di Provinsi Aceh. Jurnal Manajemen \& Agribisnis 10(2): 117-27.

Kurniawan A, Suastika G. 2013. Deteksi dan identifikasi virus pada umbi bawang merah. Jurnal Fitopatologi Indonesia 9(2): 47-52. https://doi. org/10.14692/jfi.9.2.47.

Kusuma RL, Firdaus M. 2015. Daya saing dan faktor yang memengaruhi volume ekspor sayuran Indonesia terhadap negara tujuan utama. Jurnal Manajemen \& Agribisnis 12(3): 226-236. https:// doi.org/10.17358/JMA.12.3.226.

Lakra K, Bairwa SL, Meena LK, Kushwaha S. 2014. Comparative Advantage in export major agricultural comodities in India: a post-reform analysis. Economic Affairs 59(2): 107-116. https://doi.org/10.5958/j.0976-4666.59.2.011.

Lawalata M. 2013. Analisis efisiensi relatif dan perilaku petani terhadap risiko usaha tani bawang merah di Kabupaten Bantul [tesis]. Yogyakarta: Universitas Gajah Mada.
Mayrowani H dan Darwis V. 2010. Perspektif pemasaran bawang merah di Kabupaten Brebes, Jawa Tengah. Di dalam: Suradisastra $K$, Simatupang P, Hutabarat B, editor. Prosiding Seminar Nasional Peningkatan Daya Saing Agribisnis Berorientasi Kesejahteraan Petani; 2009 Okt 14; Bogor, Indonesia. Bogor: PSEKP. hlm 169-186.

Moekasan TK, Basuki RS. 2007. Status resistensi Spodoptera exigua Hubn. pada tanaman bawang merah asal Kabupaten Cirebon, Brebes, dan Tegal terhadap insektisida yang umum digunakan petani di daerah tersebut. Jurnal Hortikultura 17(4): 343-354.

Mohanty S, Fang C, Chaudhary J. 2003. Assessing the competitiveness of Indian cotton production: a policy analysis matrix approach. Journal of Cotton Science 7(3):65-74.

Natawidjaja R.S. 2007. Pengembangan komoditas bernilai tinggi (high value commodity) untuk meningkatkan pendapatan petani. Di dalam: Suradisastra K, Yusdja Y, Hutabarat B, editor. Prosiding Seminar Nasional Dinamika Pembangunan Pertanian dan Pedesaan: Mencari Alternatif Arah pengembangan Ekonomi Rakyat. 2007 Desember 04; Bogor, Indonesia. Bogor: PSEKP. hlm 17-29.

Nurasa T dan Darwis V. 2007. Analisis usaha tani dan keragaan marjin pemasaran bawang merah di Kabupaten Brebes. Jurnal Akta Agrosia 10(1): 40-48.

Purmiyati S. 2002. Analisis produksi dan daya saing bawang merah di Kabupaten Brebes Jawa Tengah [tesis]. Bogor: Institut Pertanian Bogor.

[Pusdatin] Pusat Data dan Informasi Pertanian. 2013. Outlook Bawang Merah. Jakarta: Departemen Pertanian.

Rachman HPS, Supriyati, Saptana, Rachman B. 2004. Efisiensi dan daya saing usaha tani hortikultura. Di dalam: Saliem HP, Basuno E, Sayaka B, Sejati WK, editor. Efisiensi dan Daya Saing Sistem Usaha tani Beberapa Komoditas Pertanian di Lahan Sawah. Bogor, Indonesia. Bogor: PSEKP. hlm 50-82.

Rosenzweig C, Iglesius A, Yang XB, Epstein PR, Chivian E. 2001. Climate change and extreme weather events - Implications for food production, plant diseases, and pests. Global Change \& Human Health 2(2): 90-104. https:// doi.org/10.1023/A:1015086831467.

Rosyadi I, Purnomo D. 2014. Profitabilitas dan efisiensi 
Usaha tani bawang merah. Jurnal Ekonomi Pembangunan 15(2): 117-127.

Saptana, Sunarsih, Indraningsih KS. 2006. Mewujudkan keunggulan komparatif menjadi keunggulan kompetitif melalui pengembangan kemitraan usaha hortikultura. Forum Penelitian Agro Ekonomi 24(1): 61-76.
Supriyanti dan Rachman HPS. 2003. Efisiensi dan daya saing usaha tani bawang merah (kasus di Kabupaten Indramayu dan Majalengka, Jawa Barat). Prosiding Penerapan Teknologi Tepat Guna Dalam Mendukung Agribisnis. Bogor: PSEKP. hlm 295-302. 